\title{
Factors associated with the risk of violence against older adult women: a cross-sectional study
}

\author{
Rute Costa Régis De Sousa ${ }^{1}$ \\ (iD) https://orcid.org/0000-0002-2670-2620 \\ Gleicy Karine Nascimento De Araújo 2 \\ (iD) https://orcid.org/0000-0002-4395-6518 \\ Rafaella Queiroga Souto 3 \\ (D) https://orcid.org/0000-0002-7368-8497 \\ Renata Clemente Dos Santos ${ }^{2}$ \\ (iD) https://orcid.org/0000-0003-2916-6832 \\ Rafael Da Costa Santos ${ }^{4}$ \\ (D) https://orcid.org/0000-0001-8293-340X \\ Luana Rodrigues de Almeida ${ }^{3}$ \\ (D) https://orcid.org/0000-0003-1365-8912
}

Universidade Federal de Pernambuco, Recife, PE, Brazil.

2 Universidade Federal da Paraíba, João Pessoa, PB, Brazil.

3 Universidade Federal da Paraíba, Departamento de Enfermagem em Saúde Coletiva, João Pessoa, PB, Brazil.

${ }^{4}$ Universidade Federal da Paraíba, Escola de Enfermagem, João Pessoa, PB, Brazil.

\begin{abstract}
Objective: to identify the factors associated with the risk of violence against older adult women. Method: this is a quantitative, analytical, and cross-sectional research conducted with 122 older adult females in the city of Recife, state of Pernambuco, Brazil. Data collection was carried out using validated instruments adapted to Brazil. The analysis was performed using descriptive statistics (absolute and relative frequency) and inferential statistics (Pearson's chi- square, Spearman's correlation test, and Multiple Logistic Regression). Results: there was prevalence of a risk of abuse against older adult women under 70 years of age, literate, without a stable relationship, living alone, without any work activity, and who had an income higher than the minimum wage. There is a significant association between the risk of violence among older women with a higher number of chronic health conditions $(24 ; 77.4 \%)$, and who are less active in advanced activities $(42 ; 70.0 \%)$. A reduction in quality of life and satisfaction with life, and the onset of depressive symptoms, increase the risk of violence. Conclusion: multimorbidity, low functional capacity, depressive symptoms, low quality of life and low satisfaction with life, a high number of chronic conditions, depressive symptoms, and functional dependence to perform daily activities can be conditioning factors for the emergence of abuse against older adults.
\end{abstract}

Descriptors: Forensic Nursing; Exposure to Violence; Geriatric Nursing; Women; Public Health; Aged.

\section{How to cite this article}

Sousa RCR, Araújo GKN, Souto RQ, Santos RC, Santos RC, Almeida LR. Factors associated with the risk of violence

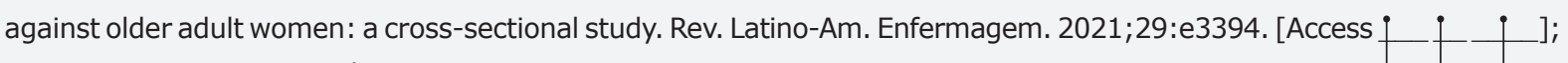
Available in: DOI: http://dx.doi.org/10.1590/1518-8345.4039.3394. 


\section{Introduction}

The increase in the number of dependent older adults can be related to the ageing process, which often comes with physical, emotional, and cognitive limitations. When associated with low social status, family unpreparedness for care provision, and a recurrent history of intra-family conflicts, such problems can all be factors in the occurrence of the phenomenon of abuse against older adults(1).

Abuse against older adults is defined as any type of action or omission that occurs individually or collectively, on a single occasion or repetitively, within a relationship where trust or expectation exists, causing harm and/or distress to the older adult(2). The discussion about the phenomenon still has little visibility in the academic community ${ }^{(3)}$; however, it deserves special attention given the vulnerability and the harms resulting from this phenomenon to public health and to the quality of life of the older population ${ }^{(4)}$.

Despite being listed in the literature, the presence of dementia, advanced age, dependence to perform basic living activities, unfavorable socioeconomic conditions, and female gender are risk factors for the older adults to be victims of violence ${ }^{(5)}$. Violence Against Older Adults (VAOA) does not occur uniformly, and it is usually found in more than one modality. For example, a study conducted in Minas Gerais, Brazil, showed a prevalence of physical and psychological violence, followed by neglect, financial violence, torture, and sexual violence(6). Older women are more likely to be victims of violence, which is predominantly perpetrated in the home and family environment ${ }^{(7)}$. Such evidence has frequently been observed in different studies and contexts(4,8-9), which leads us to consider that women are more exposed to experiencing situations of violence and, thus, that gender is a risk factor for the phenomenon. This condition of vulnerability is explained by gender inequalities, whereby women are subjugated and oppressed at all ages, and this increases in later life, when power relations involving other aggressive elements than gender can be found.

In a survey conducted with 7,257 women belonging to different age groups, $65.1 \%$ of those who were over 65 years old reported having suffered physical or sexual violence, compared to $8 \%$ of women between 16 and 49 years old, and 3\% of women aged between 50 and 65 years old(10).

In order to deal with this phenomenon, it is necessary to work with trained professionals to properly assist the older victims of violence. The area of Forensic Nursing (FN) was regulated in Brazil in 2011. It is a specialty that acts in situations of violence, such as screening and assisting the victims ${ }^{(11)}$.

A methodological study, developed with the objective of determining the skills destined to FN to care for older adults in violent situations, points out in its results that there are 47 general skills for exercise, that includes identifying confirmed and/or suspected cases of abuse against older adults, reporting cases of violence, and implementing intervention plans on victims, aggressors, and/or their families ${ }^{(12)}$.

The scope of FN in the area of abuse, sexual abuse, trauma, and other forms of violence focuses on establishing human responses in all contexts and life cycles, including the older adults, as well as developing, promoting, monitoring, and implementing responses to the harms that occur as a result of violence through the application of care practices ${ }^{(11)}$. In order to strengthen violence prevention actions, the identification of factors that influence the occurrence of violence is essential in planning an effective and resolving action ${ }^{(13)}$.

Considering the problem raised, the development of studies that understand the associated factors and abuse against older adults among individuals who live in the community is justified, in order to give greater visibility to this phenomenon and to develop an FN view of the practice among the registered nurses, enabling the proposal of possible interventions and measures to prevent abuse against older adults.

For the subject matter under discussion, the following question can be asked: What are the factors that influence the risk of abuse against older adult women? Therefore, the present study aims to identify the factors associated with the risk of violence against older adult women.

\section{Method}

This is a quantitative, descriptive, and crosssectional study guided by the STROBE (Strengthening the Reporting of Observational Studies in Epidemiology) tool, which was developed to evaluate the quality of observational studies (case-control, cohort, and crosssectional)(14), carried out from 2016 to 2017 in the city of Recife, state of Pernambuco, Brazil.

The study included all the older adults registered in the area covered by three family health teams from the Family Health Unit, located in the III Micro-area of the IV Health District, Recife, Pernambuco. The population consisted of 1,209 individuals.

The sample was calculated according to the finite population formula for epidemiological studies. With this calculation, the resulting sample consisted of 
159 older adults. For evaluation purposes, only data referring to female participants were used since this is a population more vulnerable to violence, as pointed out in the literature(5), which included 122 individuals.

Systematic random sampling was used, and the number of participants was determined proportionally among the three teams of the health unit. Out of every five older adults on each team's list, one was chosen and invited to take part in the survey.

The study included individuals aged 60 or over, and excluded those who had severe hearing (low hearing acuity or deafness) or visual (low visual acuity or blindness) impairments. The respective exclusion criteria were detected by the researcher through observation or information from those responsible for them. A total of 17 individuals were excluded due to these criteria.

The place of data collection was the home of the older adult, after explanation of the research objectives and data confidentiality. Subsequently, the individual who was available and had interest in participating signed the Free and Informed Consent Form (FICF). The participants received no financial incentive to participate in the survey.

The interviewer was accompanied by the Community Health Agent to the home of the older adult in order to provide maximum safety, as the agent is a member of the health team and knows the community.

In order that the participants' schooling level did not prevent them from reading and answering the questions, the researcher read aloud all the questions from the questionnaires. In addition, the interviewer asked to conduct the survey only with the interviewee, in a private space, thereby building a more favorable environment for the older adult to feel safe in answering questions which were mainly related to violence.

Data collection lasted approximately 40 minutes. No losses were observed in the development of the research since the researcher clarified that collection could be interrupted and resumed at other times.

The following validated instruments adapted to Brazil were used for data collection: the Brazil Old Age Schedule (BOAS) ${ }^{(15)}$; the Hwalek-Sengstock Elder Abuse Screening Test (H-S/EAST) ${ }^{(16)}$; the Self-Reported Chronic Conditions questionnaire ${ }^{(17)}$; the Mini Mental State Examination $(\text { MMSE) })^{(18)}$; Advanced Activities of Daily Living (AADLs)(19); Instrumental Activities of Daily Living (IADLs)(20); Basic Activities of Daily Living (BADLs) ${ }^{(21)}$; and the World Health Organization Quality of Life (WHOQOL-OLD) module(22).
The sociodemographic characterization of the assessed population was performed using the BOAS instrument, which is divided into sections that include general information, physical health, and use of medical, dental, and mental health services(15). Questions were extracted from this instrument referring to age, marital status, literacy, housing arrangements, work, and income (6 questions).

The $\mathrm{H}$-S/EAST is an American instrument, consisting of 15 questions that analyze the risk of abuse against older adults. One point is given for each affirmative answer, except for items 1, 6, 12, and 14, where the point is given for negative answers. A score of three or more indicates an increased risk of a type of violence present ${ }^{(16)}$.

The Self-Reported Chronic Conditions questionnaire assesses, in 7 questions, the presence of chronic pathologies, namely: angina or infarction, stroke or cerebrovascular accident (CVA), cancer, arthritis or rheumatism, lung disease, depression, and osteoporosis(17). The MMSE was applied to assess cognitive impairment among the older adults by means of 30 questions. The score of this instrument can range from 0 to 30 points, where the cutoff can vary according to the interviewee's schooling, being at 13 points for illiteracy, 18 for individuals with a low or medium schooling level, and 26 for those with a high level of schooling(18).

The participants' functional capacity was assessed according to the AADLs, IADLs and BADLs. The AADLs are 12 adapted questions that refer to the participation of the older adults in more complex activities such as educational, civic, religious, and leisure activities, offering three possible answers: never done, stopped doing, and still does. The individuals who perform only three or fewer activities are classified as less active ${ }^{(19)}$. The IADLs are 7 questions about activities of medium complexity such as telephone use, use of transportation, performing purchases, and money management ${ }^{(20)}$, while the BADLs were based on the Katz index, verifying functions such as moving around, hygiene, feeding, and sphincter control in 6 questions. All the scales classified the older adults as independent or dependent based on the need for help or the inability to perform any of the activities evaluated(21).

The WHOQOL-OLD module assesses quality of life. It consists of 24 questions and the answers are indicated on a Likert scale (from 1 to 5 ) attributed to six elements, namely: sensory functioning; autonomy; past, present and future activities; social participation; death and dying; and intimacy ${ }^{(22)}$. 
The risk of violence was the dependent variable. The independent variables were the following: age, marital status, literacy, payed work, income, living arrangement, chronic conditions, activities of daily living, quality of life, and cognitive impairment.

The collected data were inserted in the double entry modality by independent typists in the Statistical Package for the Social Sciences (SPSS), version 21.0, and the disagreements were reviewed and corrected by the data collection coordinator.

Subsequently, data analysis was performed using descriptive (absolute and relative frequency) and inferential (Pearson chi-square, Spearman correlation test, and Multiple Logistic Regression) statistics. The non-parametric test was established because, according to the result of the Kolmogorov-Smirnov normality test, the variables did not present normal distribution. A significance level of $5 \%(p<0.05)$ was adopted for all the analyses.

The entry criteria of the variables in the logistic regression model was set at $p<0.02$ based on the result of the association test. In the end, a value of 0.05 or less was considered significant.

This research was submitted to the Ethics and Research Committee of the Federal University of Pernambuco for consideration and was approved under Opinion No. 1413599/16. All the recommendations and ethical principles foresaw in research involving human beings have been respected and followed in accordance with Resolution 466/12, established by the Brazilian Health Council.

\section{Results}

In the sample there was prevalence of women with a maximum age of 70 years old $(72 ; 59.0 \%)$; literate $(85 ; 69.7 \%)$; single $(92 ; 75.4 \%)$; living with someone $(106 ; 86.9 \%)$; not working $(103 ; 88.0 \%)$; and with an income of up to 1 minimum wage $(94 ; 77.0 \%)$. The risk of violence was present in $59.0 \%(n=72)$ of the interviewees.

Table 1 below shows the data regarding the association between these characteristics and the risk of violence. No statistically significant association was observed between the variables; however, there was prevalence of the risk of violence for older women over 70 years of age, those who were literate, without a stable relationship, living alone, those who had no work activity, and those with an income greater than one minimum wage.
Table 1 - Risk of violence as a function of the sociodemographic characteristics of the older adult women taking part in the survey. Recife, PE, Brazil, 2016-2017, N=122

\begin{tabular}{|c|c|c|c|}
\hline \multirow{2}{*}{ Variables } & \multicolumn{2}{|c|}{ Risk of violence } & \multirow{2}{*}{ p-value } \\
\hline & $\begin{array}{l}\text { With } \\
\text { risk }\end{array}$ & $\begin{array}{l}\text { Without } \\
\text { risk }\end{array}$ & \\
\hline Age & n (\%) & n (\%) & \\
\hline$\leq 70$ years old & $42(58.3)$ & $30(41.7)$ & 0.85 \\
\hline$>70$ years old & $30(60.0)$ & $20(40.0)$ & \\
\hline \multicolumn{4}{|l|}{ Literate } \\
\hline Yes & $51(60.0)$ & $34(40.0)$ & 0.73 \\
\hline No & $21(56.8)$ & $16(43.2)$ & \\
\hline \multicolumn{4}{|l|}{ Marital status } \\
\hline Married/Living together & $17(56.7)$ & $13(43.3)$ & 0.76 \\
\hline $\begin{array}{l}\text { Widowed/Separated/ Never } \\
\text { married }\end{array}$ & $55(59.8)$ & $37(40.2)$ & \\
\hline \multicolumn{4}{|l|}{ Living arrangement } \\
\hline Lives alone & $10(62.5)$ & $6(37.5)$ & 0.76 \\
\hline Lives with someone & $62(58.5)$ & $44(41.5)$ & \\
\hline \multicolumn{4}{|l|}{ Working now? } \\
\hline Yes & $6(42.9)$ & $8(57.1)$ & 0.19 \\
\hline No & $63(61.2)$ & $40(38.8)$ & \\
\hline \multicolumn{4}{|l|}{ Monthly income } \\
\hline Up to 1 minimum wage & $54(57.4)$ & $40(42.6)$ & 0.51 \\
\hline More than 1 minimum wage & $18(64.3)$ & $10(35.7)$ & \\
\hline
\end{tabular}

${ }^{*}$ Pearson's chi-square test

Table 2 presents the risk of violence according to certain factors such as the number of self-reported chronic conditions, and the advanced, instrumental, and basic activities of daily living. There is a significant association between the risk of violence against older women and the higher number of chronic conditions ( $24 ; 77.4 \%)$, and less activity ( $42 ; 70.0 \%)$, according to the AADL scale. The crossing of the risk of violence and the IADL and BADL scales was not significant; however, dependence was predominant among older adult women at risk of violence.

Table 3 shows the multiple logistic regression model corresponding to the risk of violence. Only variables with $p<0.02$ in the bivariate analyses were included in the model. The data allow us to infer that older women with 4 to 7 chronic conditions who are less active are 2.69 and 2.22 times more likely to develop some risk of violence, respectively. 
Table 2 - Association of the risk of violence and the factors evaluated among the participants of the survey. Recife, PE, Brazil, 2016-2017, N=122

\begin{tabular}{|c|c|c|c|}
\hline \multirow{3}{*}{ Variables } & \multicolumn{2}{|c|}{ Risk of violence } & \multirow{3}{*}{ p-value } \\
\hline & With risk & Without risk & \\
\hline & n (\%) & n (\%) & \\
\hline \multicolumn{4}{|c|}{ No. of self-reported chronic conditions } \\
\hline 0 to 3 & $48(52.7)$ & $43(47.3)$ & 0.01 \\
\hline 4 to 7 & $24(77.4)$ & $7(22.6)$ & \\
\hline \multicolumn{4}{|l|}{$\mathrm{AADLs}^{\dagger}$} \\
\hline More active & $30(48.4)$ & $32(51.6)$ & 0.01 \\
\hline Less active & $42(70.0)$ & $18(30.0)$ & \\
\hline \multicolumn{4}{|l|}{ IADLs ${ }^{\ddagger}$} \\
\hline Independent & $30(53.6)$ & $26(46.4)$ & 0.21 \\
\hline Dependent & $42(64.6)$ & $23(35.4)$ & \\
\hline \multicolumn{4}{|l|}{ BADLs $s^{\S}$} \\
\hline Independent & $55(57.3)$ & $41(42.7)$ & 0.33 \\
\hline Dependent & $17(68.0)$ & $8(32.0)$ & \\
\hline
\end{tabular}

*Pearson's chi-square test; ${ }^{+} \mathrm{AADL}=$ Advanced activities of daily living; ${ }^{*} \mathrm{IADL}=$ Instrumental activities of daily living; ${ }^{\S} \mathrm{BADL}=$ Basic activities of daily living

Table 3 - Variables associated to the risk of violence through adjusted logistic regression. Recife, PE, Brazil, 2016-2017, N=122

\begin{tabular}{|c|c|c|c|}
\hline Variables & OR $^{*}$ & $\mathrm{Cl}^{\dagger}$ & p-value $\ddagger$ \\
\hline \multicolumn{4}{|c|}{ No. of self-reported conditions } \\
\hline 0 to 3 & 1.00 & - & - \\
\hline 4 to 7 & 2.69 & {$[1.03-7.01]$} & 0.04 \\
\hline \multicolumn{4}{|c|}{ Advanced daily living activities } \\
\hline More active & 1.00 & - & - \\
\hline Less active & 2.22 & {$[1.03-4.75]$} & 0.04 \\
\hline
\end{tabular}

Adjusted $\mathrm{R}^{2}$ : 0.111 ; Accuracy of the test: $0.336 ;{ }^{*} \mathrm{OR}=$ Odds ratio; ${ }^{+} \mathrm{CI}=$ Confidence interval; ${ }^{\ddagger}$ Significance of the test.

Table 4 shows the result of the correlation analysis between the total scores of the H-S/EAST, MMSE, and WHOQOL instruments. Through the negative correlation, it can be observed that, as quality of life decreases, the older adults are at a higher risk of violence.

Table 4 - Correlation between the total score of the $\mathrm{H}-\mathrm{S} / \mathrm{EAST}$ and the total scores of MEEM and WHOQOL. Recife, PE, Brazil, 2016-2017, N=122

\begin{tabular}{lcc}
\hline \multirow{2}{*}{ Variables } & \multicolumn{2}{c}{ Total score of H-S/EAST } \\
\cline { 2 - 3 } & Correlation coefficient & p-value $^{\dagger}$ \\
\hline Total score of MMSE ${ }^{\ddagger}$ & 0.008 & 0.934 \\
Total score of WHOQOL & -0.253 & 0.007
\end{tabular}

${ }^{*} \mathrm{H}-\mathrm{S} /$ EAST $=$ Hwalek-Sengstock Elder Abuse Screening Test; ${ }^{+}$Spearman Correlation Test; ${ }^{\ddagger}$ MMSE $=$ Mini Mental State Examination; ${ }^{5} \mathrm{WHOQOL}=$ World Health Organization Quality of Life module

\section{Discussion}

Considering the predictive factors as a guide for the professional practice enables the professional to turn care to the real needs of the study population. When referring to VAOA, FN aims to improve the assistance to cases considered forensic by presenting specific skills to face this phenomenon ${ }^{(23)}$. The sample characterization data indicates the situations of predominance for the risk of violence among older adults, which need a view of Nursing from the forensic perspective.

The participants who attained the risk score for abuse were predominantly over the age of 70 ; this data corroborates those found in some studies in the literature(24-25), such as a study conducted in Iran in which abuse is present in $93 \%(n=57)$ of the women over 72 years old ${ }^{(26)}$. Women in this age group can be at greater risk of violence due to the increased vulnerability that accompanies advancing age ${ }^{(24)}$.

The results showed that literacy was characterized as a risk factor for violence in older adult women, diverging from the literature, which states that older adults with low schooling levels are more likely to suffer abuse(27). However, another study asserted that the risk of sexual or physical violence increases as the years of study increase ${ }^{(28)}$. The prevalence of risk among the older adults can be justified by the better perception of violence among those with a higher schooling level.

Despite not being statistically significant, marital status is also a risk factor when it comes to violence. A systematic review recorded that not being in a relationship is a factor associated with violence in older adults ${ }^{(29)}$, and another study shows this same marital profile in women with a higher prevalence of physical and sexual violence ${ }^{(30)}$.

It is possible to verify that the risk was more prevalent among those who earned more than one minimum wage. Another study conducted with older Chinese women living in the United States found similar results, i.e., that abuse was more prevalent among individuals with higher income levels(31). These findings seem contradictory since older adult women who have financial difficulties are 2.5 times more likely to suffer more severe abuse ${ }^{(32)}$. Nonetheless, considering that many older adults contribute significantly to the family income, this leads to older women with greater economic power to be at a greater risk of abuse, which can be perpetrated by the family members themselves through the appropriation of the money or property belonging to this older adult woman(33).

An association $(p=0.01)$ was found between the number of self-reported conditions and the risk of violence and, in logistic regression, older adult women 
who reported the highest number of conditions, i.e., the greatest multimorbidity, were 2.69 times more likely to be at risk of abuse $(\mathrm{CI}=95 \%, 1.03-7.01)$. The longer life expectancy of women compared to men in Brazil(34) and worldwide(35) has led to a feminization of old age ${ }^{(36)}$, without this automatically translating into healthy aging, leading to a high prevalence of multimorbidity in older women and older people in general(37-39).

Multimorbidity is the occurrence of two or more chronic conditions in the same individual(40), and it is associated with elements such as loss of functional capacity(39,41), decreased grip strength(40), frailty(42), and cognitive impairment ${ }^{(43)}$, all of which are also associated with abuse against older adults. In addition, the literature shows that older adults with a high number of comorbidities have a higher chance of suffering violence $^{(44)}$. Reinforcing this analysis, a study developed in Dakahlia, Egypt, with 272 older adults concluded, based on the regression analysis, that having no chronic comorbidities is a protective factor for older adult women ${ }^{(45)}$.

The decrease in functional capacity potentially induced by the presence of morbidities associated with the risk of violence is a very evident fact when we analyze Table 2, where it is observed that the older adult women who are less active in AADLs had higher prevalence $(70.0 \%, n=42)$ of risk of violence $(p=0.01)$; and Table 3, which shows that older adults who are less active in AADLs are 2.22 times more likely to be at risk of abuse (CI=95\%, 1.03-4.75).

$\mathrm{FN}$ is responsible for acting in the prevention of VAOA, as well as for planning actions that prevent or minimize functional decline, which is recognized as a measure that can reduce the risk of violence among this population ${ }^{(46-47)}$. The literature indicates that the functional dependence of the older adult can increase exposure to violence by 2.20 times, as it increases the dependence relationship between the older victims and the likely aggressor(48).

A research study developed in Rio de Janeiro with dependent older adults sought to list the factors associated with violence and, in the findings from the association, they observed a higher prevalence of violence among older adults with cognitive impairment ${ }^{(49)}$. There are few notes in the literature that show the correlation between the risk of violence and the cognitive impairment that was observed in the results of the present study, so that it is not possible to determine the relationship between cause and effect for both outcomes. A high cognitive deficit can increase the risk of violence, as well as the risk of violence can worsen the cognitive function of older adult women ${ }^{(50)}$.
Another variable that also correlated with the risk of abuse was the WHOQOL total score: the correlation coefficient was negative, thus pointing to an inversely proportional relationship between the two variables, i.e., the higher the WHOQOL score (higher quality of life), the lower the HS-EAST score (lower risk of abuse), or vice versa.

A study conducted with older adults in China found that self-neglect is a risk factor for deficient quality of life ${ }^{(51)}$, and that other factors also associated with quality of life ${ }^{(52)}$ are years of study, self-rated health, number of chronic conditions, and physical activity ${ }^{(53)}$.

Quality of life is also associated with the prejudice that the older adults have about themselves and about aging, so FN is responsible for promoting positive attitudes towards old age and the self-perception of older adult women, thus leading to an improvement in quality of life and, consequently, to a reduced likelihood of abuse(54-55).

The results support the focus of the performance of FN for the study population, pointing out that functional capacity, cognitive decline, and quality of life, are factors that increase the risk of violence among older adults, so any intervention in these aspects can be satisfactory in preventing violence. In addition, these factors should attract the attention of forensic nurses in screening older adults who are victims of violence ${ }^{(13)}$.

The study limitations include the absence of validated instruments for the Brazilian scenario that identify all types of violence, restricting the deepening of the discussion on this phenomenon. In addition, there is a lack of studies that relate $\mathrm{FN}$ and its exercise in the context of VAOA, thus preventing a clear understanding of the scientific Nursing community about this field of action.

\section{Conclusion}

It can be concluded that factors such as multimorbidity, low functional capacity, depressive symptoms, low quality of life and low satisfaction with life, depressive symptoms, and functional dependence for daily activities, are associated with the risk of violence against older adult women.

The study contributes to the academic field and to the Nursing practice since it provides subsidies for decision-making based on proven evidence, which demonstrates the predictive factors of violence against older adult women. In addition, it also to strengthens the field of work of $\mathrm{FN}$, as well as conducting new research studies of situational diagnosis and proposing interventions to combat the phenomenon of violence. 


\section{References}

1. Belisário MS, Dias FA, Pegorari MS, Paiva MM, Ferreira PCS, Corradini FA, et al. Cross-sectional study on the association between frailty and violence against community-dwelling elderly people in Brazil. São Paulo Med J. [Internet]. 2017 Dec [cited Mar 10, 2019];136(1):10-9. Available from: 10.1590/1516-3180.2017.0203290817 2. World Health Organization. The Toronto Declaration on the Global Prevention of Elder Abuse. Geneva: WHO; 2002.

3. Santana IO, Vasconcelos DC, Lima Coutinho MP. Prevalência da violência contra o idoso no Brasil: revisão analítica. Arq Bras Psicol. [Internet]. 2016 [Acesso 10 mar 2019];68(1):126-39. Disponível em: http:// pepsic.bvsalud.org/sc elo.php?script=sci_arttext\&pid $=$ S1809-52672016000100011

4. Castro VC, Rissardo LK, Carreira L. Violence against the Brazilian elderlies: an analysis of hospitalizations. Rev Bras Enferm. [Internet]. 2018 [cited Mar 11, 2019];71(suppl 2):777-85. Available from: http://dx.doi. org/0.1590/0034-7167-2017-0139

5. Storey JE. Risk factors for elder abuse and neglect: A review of the literature. Aggress Violent Behav. 2020 Jan;50:101339. doi: 10.1016/j.avb.2019.101339

6. Oliveira GF, Cunha BRR, Souza ADC, Giorgiani M, Batista JRR, Alves PMR, et al. Epidemiological Profile of Violence against the Elderly in the State of Minas Gerais, Brazil. SciMedicine J. 2019 Jun;1(2):38-47. doi: 10.28991/SciMedJ-2019-0102-1

7. Silva GCN, Almeida VL, Brito TRP, Godinho MLC, Nogueira DA, Chini LT. Violência contra idosos em um município do sul de Minas Gerais: uma análise documental. Aquichan. $2018 \mathrm{Dec} ; 18(4): 449-60$. doi: 10.5294/ aqui.2018.18.4.7

8. Alencar Junior FO, Moraes JR. Prevalência e fatores associados à violência contra idosos cometida por pessoas desconhecidas, Brasil, 2013. Epidemiol Serv Saúde. 2018 May;27(2). doi: 10.5123/s1679-49742018000200009

9. Dantas RB, Oliveira GL, Silveira AM. Psychometric properties of the Vulnerability to Abuse Screening Scale for screening abuse of older adults. Rev Saude Publica. 2017;51. doi: 10.1590/s1518-8787.2017051006839

10. Knight L, Hester M. Domestic violence and mental health in older adults. Int Rev Psychiatry. 2016 Sep;28(5):46474. doi: 10.1080/09540261.2016.1215294

11. Associação Brasileira de Enfermagem Forense. Regulamento das competências técnicas da enfermagem forense. [Internet]. Aracaju: ABENFORENSE; 2015 [Acesso 12 abr 2019]. Disponível em: http://www.abeforense.org. br/wp-content/uploads/2016/06/Competências-Tecnicasda-Enfermagem-Forense.pdf
12. Du Mont J, Kosa D, Macdonald S, Elliot S, Yaffe M. Development of skills-based competencies for forensic nurse examiners providing elder abuse care. BMJ Open. 2016;6(2):1-8. doi: 10.1136/bmjopen-2015-009690

13. Du Mont J, Kosa D, Yang R, Solomon S, Macdonald $S$. Determining the effectiveness of an Elder Abuse Nurse Examiner Curriculum: A pilot study. Nurse Educ Today. [Internet]. 2017 Aug [cited Apr 23, 2020];55:716. Available from: https://doi.org/10.1016/j. nedt.2017.05.002

14. Cheng A, Kessler D, Mackinnon R, Chang TP, Nadkarni VM, Hunt EA, et al. Reporting Guidelines for Health Care Simulation Research. Simul Healthc J Soc Simul Healthc. 2016 Aug;11(4):238-48. doi: 10.1097/ SIH.0000000000000150

15. Veras RP, Souza CAM, Cardoso RF, Milioli R, Silva SD. Pesquisando populações idosas - A importância do instrumento e o treinamento de equipe: uma contribuição metodológica. Rev Saude Publica. 1988 Dez;22(6):513-8. doi: 10.1590/S0034-89101988000600008

16. Reichenheim ME, Paixão Jr CM, Moraes CL. Adaptação transcultural para o português (Brasil) do instrumento Hwalek-Sengstock Elder Abuse Screening Test (H-S/ EAST) utilizado para identificar risco de violência contra o idoso. Cad Saude Publica. 2008 Aug;24(8):1801-13. doi: 10.1590/S0102-311X2008000800009

17. Domingues PC, Neri AL. Atividade física habitual, sintomas depressivos e doenças auto-relatadas em idosos da comunidade. Rev Bras Ativ Física Saúde. 2009;14(3):164-73. doi: 10.12820/rbafs.v.14n3p164-173 18. Lourenço RA, Veras RP. Mini-Exame do Estado Mental: características psicométricas em idosos ambulatoriais. Rev Saude Publica. 2006 Aug;40(4):712-9. doi: 10.1590/ S0034-89102006000500023

19. Oliveira EM, Silva HS, Lopes A, Cachioni M, Falcão DVS, Batistoni SST, et al. Atividades Avançadas de Vida Diária (AAVD) e desempenho cognitivo entre idosos. Psico-USF. 2015 Apr;20(1):109-20. doi: 10.1590/141382712015200110

20. Santos RL, Virtuoso Júnior JS. Confiabilidade da versão brasileira da Escala de Atividades Instrumentais da Vida Diária. Rev Bras Promoção Saúde. 2008;290-6. doi: 10.5020/18061230.2008.p290

21. Duarte YAO, Andrade CL, Lebrão ML. O Índex de Katz na avaliação da funcionalidade dos idosos. Rev Esc Enferm USP. 2007 Jun;41(2):317-25. doi: 10.1590/ S0080-62342007000200021

22. Fleck MP, Chachamovich E, Trentini C. Development and validation of the Portuguese version of the WHOQOLOLD module. Rev Saude Publica. 2006 Oct;40(5):785-91. doi: 10.1590/S0034-89102006000600007

23. Paiva MHP, Lages LP, Medeiros ZC. Studies on forensic nursing in Brazil: a systematic review of the 
literature. Int Nurs Rev. [Internet]. 2017 Jun [cited Jun 29, 2020];64(2):286-95. doi: 10.1111/inr.12328

24. Guimarães APS, Górios C, Rodrigues CL, Armond JE. Notification of intrafamily violence against elderly women in the city of São Paulo. Rev Bras Geriatr Gerontol. 2018 Feb;21(1):88-94. doi: 10.1590/198122562018021.160213

25. Hernández RR, Esquivel-Santoveña EE. Prevalencia y factores asociados con la violencia de pareja en las adultas mayores mexicanas. Salud Colect. 2020 May; 16:e2600. doi: $10.18294 /$ sc.2020.2600

26. Sadrollahi A, Khalili Z, Ghorbani M, Mahmoodi M. The Prevalence of Various Abuse Types and Their Associated Factors in the Elderly. J Res Heal. 2020 Jan;59-66. doi: 10.32598/JRH.10.1.59

27. Bows H. Sexual Violence Against Older People: A Review of the Empirical Literature. Trauma Violence Abuse. 2018 Dec;19(5):567-83. doi: 10.1177/1524838016683455

28. Orellana JDY, Cunha GM, Marrero L, Horta BL, Leite IC. Violência urbana e fatores de risco relacionados ao feminicídio em contexto amazônico brasileiro. Cad Saude Publica. 2019;35(8). doi: http://dx.doi. org/10.1590/0102-311x00230418

29. Warmling D, Lindner SR, Coelho EBS. Prevalência de violência por parceiro íntimo em idosos e fatores associados: revisão sistemática. Cien Saude Colet. [Internet]. 2017 Sep [Acesso 23 abr 2020];22(9):311125. Disponível em: https://doi.org/10.1590/141381232017229.12312017

30. Leite FMC, Amorim MHC, Wehrmeister FC, Gigante DP. Violence against women, Espírito Santo, Brazil. Rev Saude Publica. [Internet]. 2017 [cited Apr 23, 2020];51. Available from: https://doi.org/10.1590/ s1518-8787.2017051006815

31. Dong $X$, Chen $R$, Simon MA. Elder Mistreatment in U.S. Community-Dwelling Chinese Older Women. Violence Against Women. 2016 Aug 27;22(9):1097-112. doi: $10.1177 / 1077801215618804$

32. Donder L, Lang G, Ferreira-Alves J, Penhale B, Tamutiene I, Luoma ML. Risk factors of severity of abuse against older women in the home setting: a multinational European study. J Women Aging. 2016 Nov;28(6):540-54. doi: 10.1080/08952841.2016.1223933

33. Alarcon MFS, Paes VP, Damaceno DG, Sponchiado VBY, Marin MJS. Financial abuse: circumstances of occurrences against older adults. Rev Bras Geriatr Gerontol. 2019;22(6). doi: 10.1590/1981-22562019022.190182 34. Instituto Brasileiro de Geografia e Estatística. Síntese de indicadores sociais: Uma análise das condições de vida da população brasileira 2018. [Internet]. 2018 [Acesso 5 jun 2019]. Disponível em: https://biblioteca.ibge. gov.br/index.php/biblioteca-catalogo?view=detalhes\& id $=2101629$
35. Kontis V, Bennett JE, Mathers CD, Li G, Foreman K, Ezzati M. Future life expectancy in 35 industrialised countries: projections with a Bayesian model ensemble. Lancet. 2017;389(10076):1323-35. doi: 10.1016/S01406736(16)32381-9

36. Carney GM. Toward a gender politics of aging. J Women Aging. 2018 May;30(3):242-58. doi: 10.1080/08952841.2017.1301163

37. Bell SP, Saraf AA. Epidemiology of Multimorbidity in Older Adults with Cardiovascular Disease. Clin Geriatr Med. 2016 May;32(2):215-26. doi: 10.1016/j. cger.2016.01.013

38. Lin H, Li Q, Hu Y, Zhu C, Ma H, Gao J, et al. The prevalence of multiple non-communicable diseases among middle-aged and elderly people: the Shanghai Changfeng Study. Eur J Epidemiol. 2017 Feb;32(2):159-63. doi: 10.1007/s10654-016-0219-6

39. Rillamas-Sun E, LaCroix AZ, Bell CL, Ryckman $K$, Ockene JK, Wallace RB. The Impact of Multimorbidity and Coronary Disease Comorbidity on Physical Function in Women Aged 80 Years and Older: The Women's Health Initiative. J Gerontol Ser A Biol Sci Med Sci. 2016 Mar;71(Suppl 1):S54-61. doi: 10.1093/gerona/glv059 40. Volaklis KA, Halle M, Thorand B, Peters A, Ladwig $\mathrm{KH}$, Schulz $\mathrm{H}$, et al. Handgrip strength is inversely and independently associated with multimorbidity among older women: Results from the KORA-Age study. Eur J Intern Med. 2016 Jun;31:35-40. doi: 10.1016/j. ejim.2016.04.001

41. Costa Filho AM, Mambrini JVM, Malta DC, Lima-Costa MF, Peixoto SV. Contribution of chronic diseases to the prevalence of disability in basic and instrumental activities of daily living in elderly Brazilians: the National Health Survey (2013). Cad Saude Publica. 2018 Feb 5;34(1). doi: 10.1590/0102-311x00204016

42. Villacampa-Fernández $P$, Navarro-Pardo E, Tarín JJ, Cano A. Frailty and multimorbidity: Two related yet different concepts. Maturitas. 2017 Jan;95:31-5. doi: 10.1016/j.maturitas.2016.10.008

43. Loprinzi PD. Multimorbidity, cognitive function, and physical activity. Age (Omaha). 2016 Feb;38(1):8. doi: 10.1007/s11357-016-9874-5

44. Bolsoni CC, Lindner SR, D'Orsi E, Salema Coelho EB. Dimensions of Violence against the Elderly and Health Conditions: a Population-based Study in Southern Brazil. Res Ageing Soc Policy. 2019 Jul;7(2):426. doi: 10.17583/ rasp. 2019.4425

45. El-Khawaga G, Eladawi N, Abdel-Wahab F. Abuse of Rural Elders in Mansoura Districts, Dakahlia, Egypt: Prevalence, Types, Risk Factors, and Lifestyle. J Interpers Violence. 2018 Apr;1-15. doi: $10.1177 / 0886260518767900$ 
46. Kong J, Jeon H. Functional Decline and Emotional Elder Abuse: a Population-Based Study of Older Korean Adults. J Fam Violence. 2018 Jan;33(1):17-26. doi: 10.1007/s10896-017-9941-4

47. Santos AA, Silva JF, Ferreira MB, Conceição VLS, Alves DMC. Estado da arte da Enfermagem Forense no cenário atual da saúde. Rev Eletr Acervo Saúde. 2019 Jul;(27):e1015. doi: 10.25248/reas.e1015.2019

48. Sathya T, Premkumar R. Association of functional limitations and disability with elder abuse in India: a cross-sectional study. BMC Geriatr. 2020 Dec;20(1):220. doi: 10.1186/s12877-020-01619-3

49. Lino VTS, Rodrigues NCP, Lima IS, Athie S, Souza ER. Prevalência e fatores associados ao abuso de cuidadores contra idosos dependentes: a face oculta da violência familiar. Cien Saude Colet. [Internet]. 2019 Jan [Acesso 23 abr 2020];24(1):87-96. Disponível em: https://doi. org/10.1590/1413-81232018241.34872016

50. Faustino AM, Moura LBA, Gandolfi L. Relação entre violência e função cognitiva em idosos. J Nurs UFPE On Line. [Internet]. 2016 [Acesso 23 abr 2020];10(5):171723. Disponível em: https://doi.org/10.5205/1981-8963v10i5a13547p1717-1723-2016

51. Zhao Y, Hu C, Feng F, Gong F, Lu S, Qian Z, et al. Associations of self-neglect with quality of life in older people in rural China: a cross-sectional study. Int Psychogeriatrics. [Internet]. 2017 Jun [cited Jun 15, 2019];29(6):1015-26. Available from: https://doi. org/10.1017/S1041610217000229

52. Sánchez-García S, García-Peña C, Salvà-Casanovas A, Sánchez-Arenas R, Granados-García V, CuadrosMoreno J, et al. Frailty in community-dwelling older adults: association with adverse outcomes. Clin Interv Aging. [Internet]. 2017 Jun [cited Jun 16, 2019]; Volume 12:1003-11. doi: https://doi.org/10.2147/CIA.S139860. 53. Fonte $E$, Feitosa $P$, Oliveira Neto L, Araújo C, Figueiroa J, Alves J. Effects of a physical activity program on the quality of life among elderly people in Brazil. J Fam Med Prim Care. [Internet]. 2016 [cited Jun 18, 2019];5(1):139. Available from: https://doi. org/10.4103/2249-4863.184639

54. Top M, Dikmetaş E. Quality of life and attitudes to ageing in Turkish older adults at old people's homes. Heal Expect. [Internet]. 2015 Apr [cited Jun 20,
2019];18(2):288-300. Available from: https://doi. org/10.1111/hex.12032

55. Yamada Y, Merz L, Kisvetrova H. Quality of life and comorbidity among older home care clients: role of positive attitudes toward aging. Qual Life Res. [Internet]. 2015 Jul [cited Jun 20, 2019];24(7):1661-7. Available from: https://doi.org/10.1007/s11136-014-0899-x
Received: Dec 3 $3^{\text {rd }} 2019$

Accepted: Jul $15^{\text {th }} 2020$

Associate editor: Andrea Bernardes

Copyright @ 2021 Revista Latino-Americana de Enfermagem This is an Open Access article distributed under the terms of the Creative Commons (CC BY).

This license lets others distribute, remix, tweak, and build upon your work, even commercially, as long as they credit you for the original creation. This is the most accommodating of licenses offered. Recommended for maximum dissemination and use of licensed materials. 